\section{Multidisciplinary \\ SCIENTIFIC JOURNAL OF MARITIME RESEARCH}

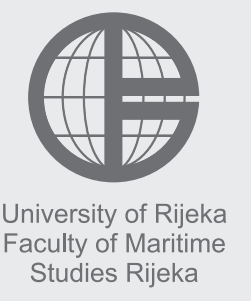

\section{Multidisciplinarni znanstveni časopis POMORSTVO}

\title{
Reorganization of the public utility companies
}

\author{
Željko Smojver ${ }^{1}$, Gorana Stumpf ${ }^{2}$, Donald Schiozzi ${ }^{3}$ \\ ${ }^{1}$ RIJEKA plus d.o.o., Školjić 15, 51000 Rijeka, Croatia, e-mail: zeljko.smojver@rijeka-plus.hr \\ ${ }^{2}$ University of Rijeka, Faculty of Maritime Studies, Studentska ulica 2,51000 Rijeka, Croatia, e-mail: stumpf@pfri.hr \\ ${ }^{3}$ Port Authority Rovinj, Obala/Riva Aldo Rismondo 2, 52210 Rovinj, Croatia, e-mail: donald@port-rovinj.hr
}

\begin{abstract}
This scientific paper includes an analysis of the provision of public city transport services and explores a new organizational model regarding the city companies, i.e. public utility companies and companies operating within a local self-government unit. The model includes separate groups of utility activities and commercial activities and centralizes the supporting functions into a new company, which will be in charge of joint affairs, thus creating a synergy. Such model ultimately generates higher revenues, higher service quality, higher operations efficiency and lower operating costs. The purpose of this scientific paper was to determine the compatibility of the public utility companies' operations within a local self-government unit and to identify areas for improvement, which would ensure more efficient business operations. Under the assumption that the existing, general organizational structure has no conditions for a more optimal functioning, it is necessary to observe the subsystems, i.e. the elements or components and to repeat the procedure until reaching a solution which improves the functioning of the system at the level of observing it as a separate whole. An analysis of the public utility system's productivity was carried out and the existence of compatibility among services, which would lead to synergies and business optimization, was examined. The research results indicate a fact that the introduction of the model for separate grouping of supporting activities and commercial activities creates a uniform quality, avoids data doubling, allows for a better workload organization and a more efficient planning leading to a higher level of productivity.
\end{abstract}

\section{ARTICLE INFO}

Review article

Received 15 May 2017

Accepted 7 June 2017

Key words:

Reorganization

Supporting functions

Commercial activity

\section{Introduction}

The provision of the public city transport services as well as the road and public traffic area maintenance includes activities, which are mutually intertwined as well as tasks, which are connected and compatible. An analysis was made regarding the productivity of the public utility companies for public passenger transport, supply of thermal energy, water services providers, cleaning services and waste management, traffic control, road and public traffic area maintenance, vehicle parking and transfer organization, and for funeral and burial matters. The criteria which were taken into consideration in the analysis of the public utility for public transport and the company for road and public traffic areas maintenance were the assessment of the concept of the new organization, strategic planning, optimal business operations, management efficiency and organizational development. The creation of new companies which consolidate the joint supporting functions on one hand and the joint commercial activities on the other is the ultimate goal of the said public utility companies. With the new organizational model both public utility companies keep their public utility activity, while the commercial activity is being separated into a new company and the supporting functions are being separated into another new company. Organization implies designed system of interactively connecting several different business functions, into one functional, uniform, naturally efficient, profitable and ecologically sustainable whole.

\section{Comparison of the public utility system for public passenger transport with the company for road maintenance}

The analysis of the public utility system showed a connection between the public utility companies and the com- 


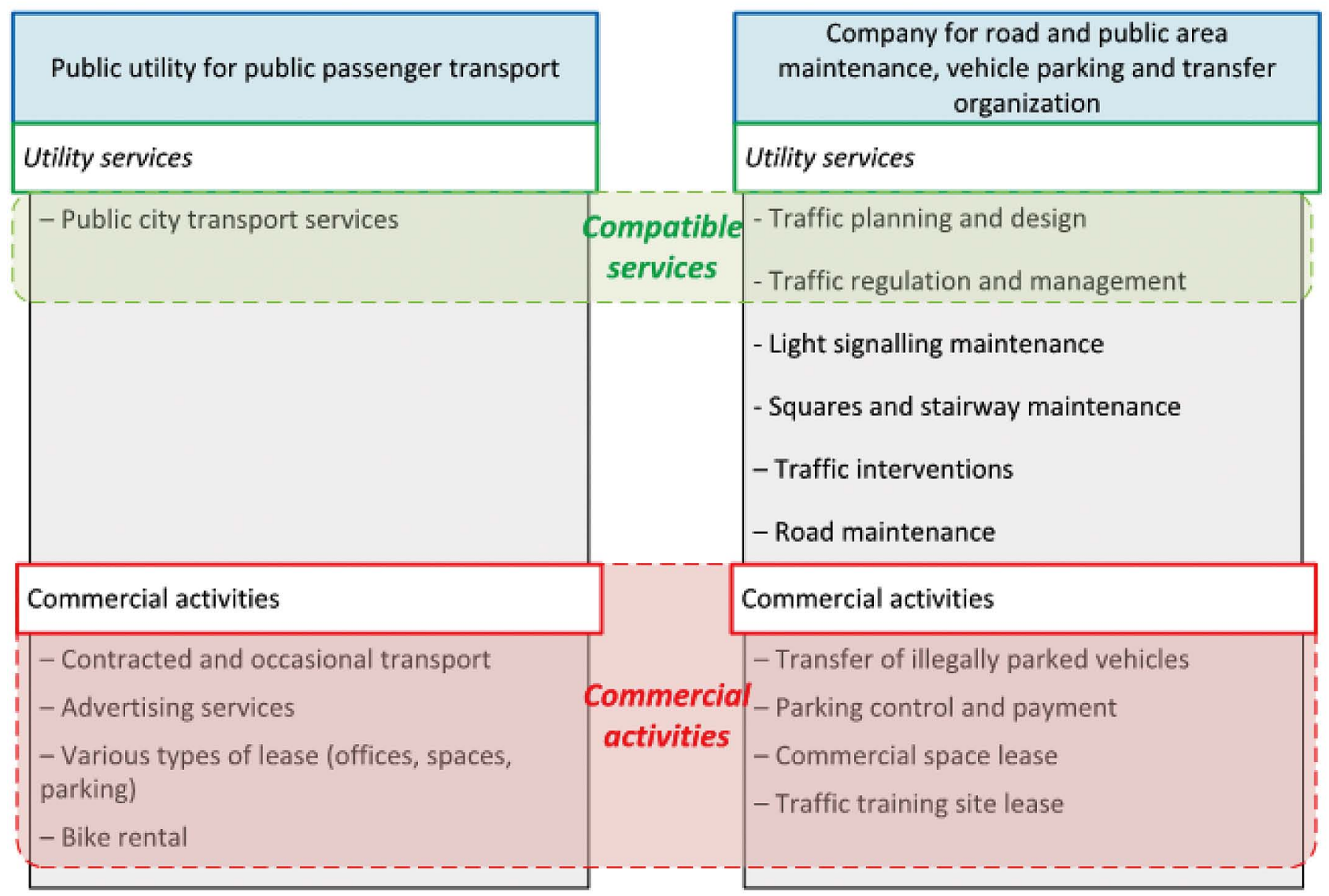

Figure 1 Comparison of the features of the public utility for public passenger transport and the company for road maintenance

Source: [1]

patibility between the services of a public utility company for public passenger transport ${ }^{1}$ and the company for road and public traffic area maintenance and vehicle parking and transfer organization. With the objective of conducting a more detailed examination of the compatibility of services of the said two companies, their services were divided into commercial and utility services and they were separately analysed which is shown in figure 1 .

As the figure shows, a high level of connectivity and compatibility was proven between the public passenger transport utility services and the planning and design of traffic, traffic regulation and management by the companies involved in road maintenance. There is significant potential for synergies between the said two companies such as development activities of the company involved in the planning and defining of the city traffic, which allows the public utility for public passenger traffic to maintain a higher quality level of the public passenger traffic service. The optimization of the public passenger road transport is a current issue for several reasons: the increasing

\footnotetext{
The public utility for public passenger transport is a joint company of a local self-government unit which is the centre of the county as the majority owner and of the neighbouring towns and municipalities. Annually it transports around 45,000,000 passengers and passes more than 10,000,000 kilometres.
}

demands for transport, avoidance of the transport system isolation, ineffectiveness and disintegration, lack of coordination of certain forms of traffic, large investments into the transportation system, environmental protection, increasing information technology related possibilities [5]. Furthermore, the services of the company for road and public traffic area maintenance enable the public utility to optimize the routes what can ultimately lead to an increased efficiency and thus have a positive mutual effect [5].

In June 2014 a concept of a new organization model for city companies was developed and accepted. The new proposal regarding the city companies' organization was defined in comparison with the best European practices in the city transport and city companies' organization. The proposed concept is based on dividing the commercial and utility services activities from the said two companies and centralizing the supporting functions of both companies. The new organization will enable the grouping of the utility services and commercial activities for specialized companies and the centralization of the supporting functions, thus allowing for increased productivity, increased service quality and creation of possibilities for future development. The main advantages which the new organizational model will offer are the increase of revenue with the im- 
provement of the service quality and increased business efficiency with lower operating costs. The said change does not mean new employee hiring or firing. Instead, the new organization will be filled with the available resources whose expertise and knowledge will be used more effectively due to the new structure [5]. In this case the work organization implies a subjectively designed system of interactively connecting several different business functions, i.e. their technological operations into one functional, uniform, naturally efficient, profitable in terms of capital, and ecologically sustainable whole [3].

\section{The new organization's structure}

\subsection{Separating the supporting functions from the public utility for public passenger transport}

The centralization of supporting functions leads to savings in procurement and other operating costs and eliminates double workload. It also enables the increase of service quality and achieving greater business efficiency. The joint supporting functions are aimed at the integration of knowledge and competences due to the employees' specialization in the process organization. The effects of centralizing the supporting functions are simplified tasks, increased speed and work efficiency, faster and easier connecting of the new companies to the joint supporting functions' system and the accumulation of the know-how. Increased productivity and more employees having the same function enable better utilisation of resources. The result of centralization is savings, i.e. the reduction of costs, the released investment potential and the higher level of services for the users. Under the assumption that the existing, general organizational structure has no conditions for a more optimal functioning, it is necessary to observe the subsystems, i.e. the elements or components and to repeat the procedure until reaching a solution which improves the functioning of the system at the level of observing it as a separate whole [2].

The areas unified in the joint company are strategic development, finances and accounting and controlling, procurement and stock management and joint departments (general, legal and personnel affairs, occupational health and safety, public relations and IT support). The departments and the overall organizational structure of the new company are presented in the following figure [3].

The Strategic Development and Projects Department is responsible for the initiation of all development projects, organization and creation of studies and surveys and medium-term and long-term development plans and programmes, evaluation of the value of the equipment and works, participation in the work of formed teams during the creation of the project documentation necessary for the realization of a certain project and participation in the

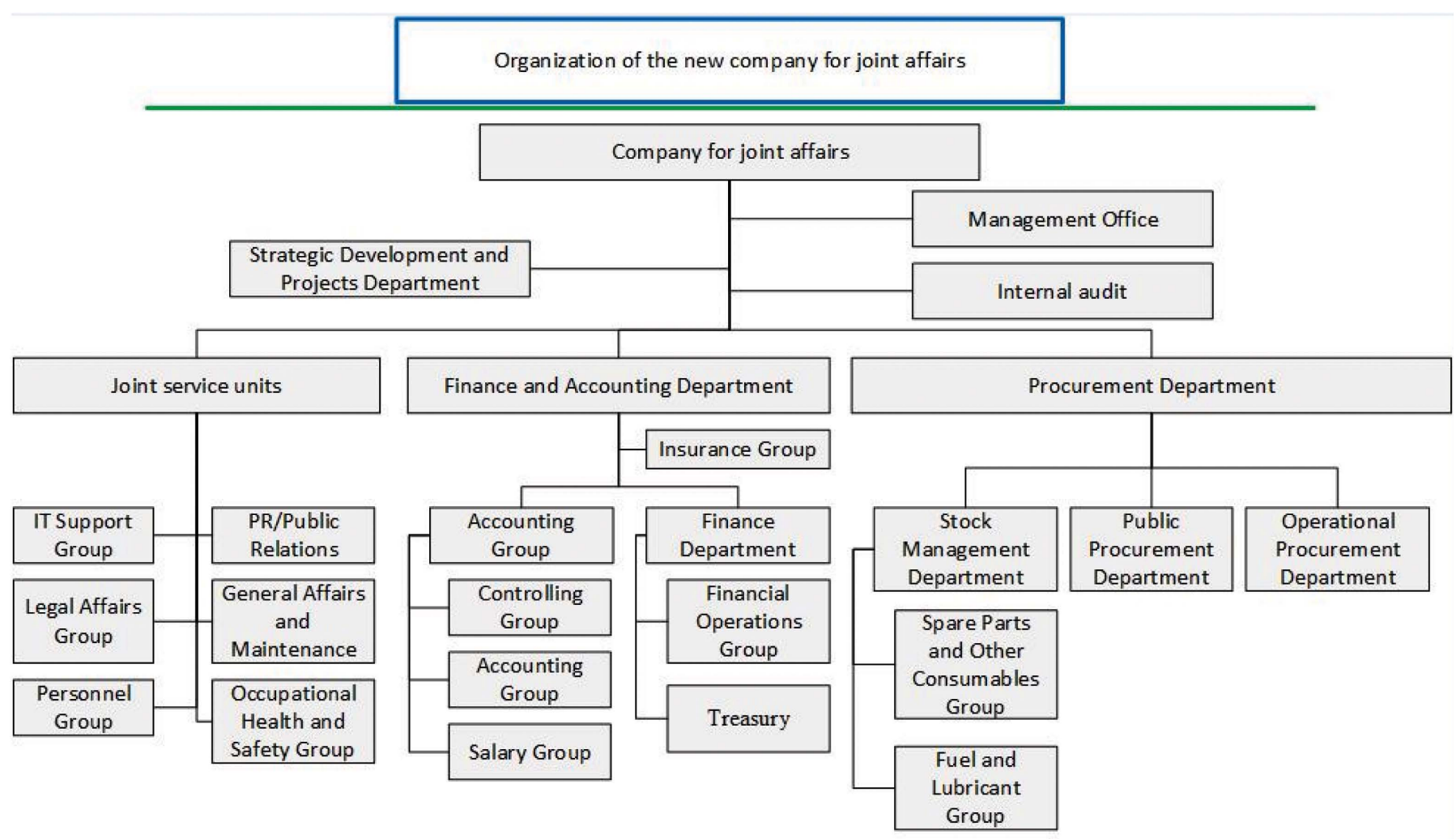

Figure 2 Organizational structure of the new company for joint affairs 
planning of the phases and monitoring the course of realization of investments projects within the formed teams. The separation of supporting functions leads to better and more quality use of people's knowledge and expertise.

The Legal, Personnel and General Affairs Department and the Public Relations Department have also been separated from the public utility for public passenger transport and they are a part of the joint departments in the joint affairs company The Information Technology Group, which was previously a part of the Finance Department, was separated and added to the same department. Joint departments will be in charge of the management and coordination of general and legal affairs, human resource management tasks, occupational health and safety and IT support, planning the need for human resources, exercising the employees' rights on the basis of collective agreements, providing legal aid to all companies, providing IT support to the users, public relations, enforcement of legal provisions and regulations regarding occupational health and safety, environmental protection and fire protection and surveillance of such affairs, and organizing, keeping and monitoring facilities and assets. ${ }^{2}$

The Finance Department of the public utility for public passenger transport was, in addition to the Information Technology Group, also separated and added to the business systems within the Finance and Accounting Department. The tasks which the Finance and Accounting Department is in charge of include the coordination of work and preparation of all accounting information for auditing purposes, managing insurance-related affairs, assets, persons and things, controlling all organizational units, closing financial constructions of all development and investment projects in cooperation with the customer support departments, creation of investment studies of investment justification and financial analyses, creation of procedures for the management of finances, accounting and controlling, and drafting of accounting policies.

A part of the commercial department of the said public utility in charge of procurement and stock management was separated and added to a new company within the Procurement Department. The Procurement Department's affairs include the management and coordination of service sales, marketing, provision of goods, works and services, making sure that the procurement is taking place in accordance with the procurement plan within the set limits of the financial means, defining and creating technical specifications based on historical data for all users, participating in the drafting of the procurement and sale agreements and direct cooperation in stock management.

\subsection{Separating the commercial activity from the public utility for public passenger transport}

The commercial activity was also extracted to a separate company while the public utility for public passenger transport and the company for road and public traffic area

\footnotetext{
Op. cit.
}

maintenance and vehicle parking and transfer organization maintain their utility services activity and legal personality. The new organization is especially important because it enables a unique implementation of strategies, higher quality and efficiency and more efficient commercial operations. Furthermore, one of the motivating factors for the formation of a new company for commercial activity is also the compliance with the European Union's regulations and achieving greater business efficiency. The following figure shows the organizational structure, i.e. the newly-founded departments and their tasks within the new company for commercial activity [4].

With the goal of reaching a better understanding of the business processes and activities within the Maintenance Department and connectivity with the Traffic Department of the public utility for public passenger transport, the process of control and maintenance of vehicles was analysed and it was concluded that a part of the Maintenance Department in charge of maintenance quality will remain within the public utility. Furthermore, the part relating to vehicle repairs is being transferred to a new company for commercial activity, thus creating a competence centre for the maintenance of potentially all vehicles in the utility services sector. This creates an organizational and resource-related prerequisite for the foundation of the competence centre for the maintenance of all vehicles in the utility services sector and the local self-government units of the said company, as well as for the generation of additional revenues by providing services on the market.

The Vehicle Maintenance Department is in charge of preventive and corrective maintenance of vehicles, facilities and machines, defining and creating technical specifications regarding the procurement of goods, works and services for tendering in cooperation with the Department for Sale and Control of Payment, and ensuring the planned technical validity of the users' vehicles.

A Parking Department was set up within the new company for commercial activity and it includes the commercial activity of the Parking Sector of the company for road and public area maintenance, vehicle parking and transfer organization.

Furthermore, the Sale and Marketing Department was transferred to the new company for commercial activity which provides the public utility for public passenger transport with the services of sales of tickets, free bus capacities and advertising space on and in the buses. The Sale and Marketing Department is a part of the Department for Sale and Control Payment. The Passenger Ticket Control Department, which was previously a part of the Legal, Personnel and General Affairs Department, was also transferred to the Sale and Marketing Department. The Passenger Ticket Control Department's main tasks are the control of passenger tickets, including the control of timetable accuracy, vehicle cleanliness, traffic personnel's proper appearance and behaviour towards the passengers, and control of issuing and collecting the payment of tickets as well as passenger control in terms of determining the legitimacy of their ride. A part of the Public 


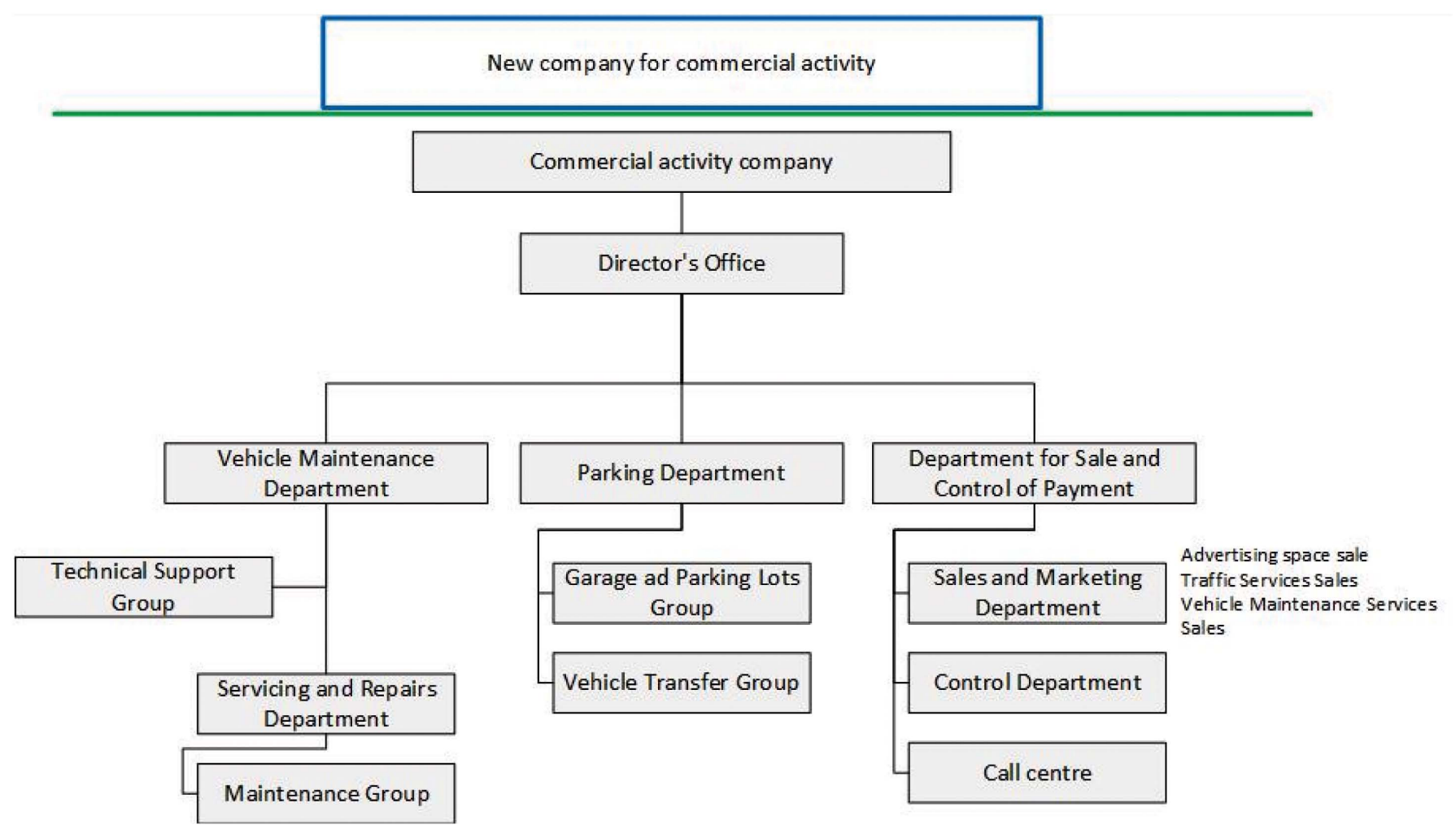

Figure 3 Organizational structure of the new company for commercial activity

Source: [4]

Relations Department which works in the call centre and provides the users with timely information was also transferred to the same Department.

Other tasks of the Department for Sale and Control Payment include the management and coordination of the services of sale and marketing, participation in the creation of the sales agreement for the company and external service users in accordance with the positive legal regulations, ensuring maximum revenues for the company and external users, both within regular and special activities (special purpose transport, advertising on and in buses, selling secondary raw materials, commercial space lease etc.), defining policies and guidelines regarding the control of tickets and traffic personnel and controlling their implementation.

The separation of the supporting functions and the supporting activities from the initial companies enables a better and more quality utilisation of people's knowledge and expertise, reduces the costs and encourages efficient business operations [4].

\section{Cooperation agreement in the new organization}

Certain company services in the new organization are invoiced separately in order to estimate the costs of each company individually. The key assumptions for the simulation of the revenue, expenditure and their mutual invoicing are separating the utility services and commercial activities, separating the supporting services, not sharing the assets all the existing assets of the public utility for public passenger transport remains in the company ownership, keeping the existing amount of the budgetary expenses and an assumption that the public utility for passenger transport, the company for traffic planning, road and public area maintenance and the new company with joint departments gain profit before taxation 0 , whereas the company for commercial activity is the only one generating profit.

The division of activities and the assumption of not sharing the assets generate additional revenues and expenditures arising from mutual invoicing. The public utility for passenger transport in the new organization accepts three types of purchase invoices: from the company with joint departments and the company for commercial activity, and it issues two types of sales invoices of the company with joint departments and the company for commercial activity [4].

Purchase invoices refer to:

- Invoice C1: Provision of corporate services which will include the following services: legal affairs, human resources, general affairs, including occupational health and safety, procurement and storage, public relations, IT support (software and hardware maintenance), finances and accounting, strategic development, internal audit. 


\section{SALES INVOICES}

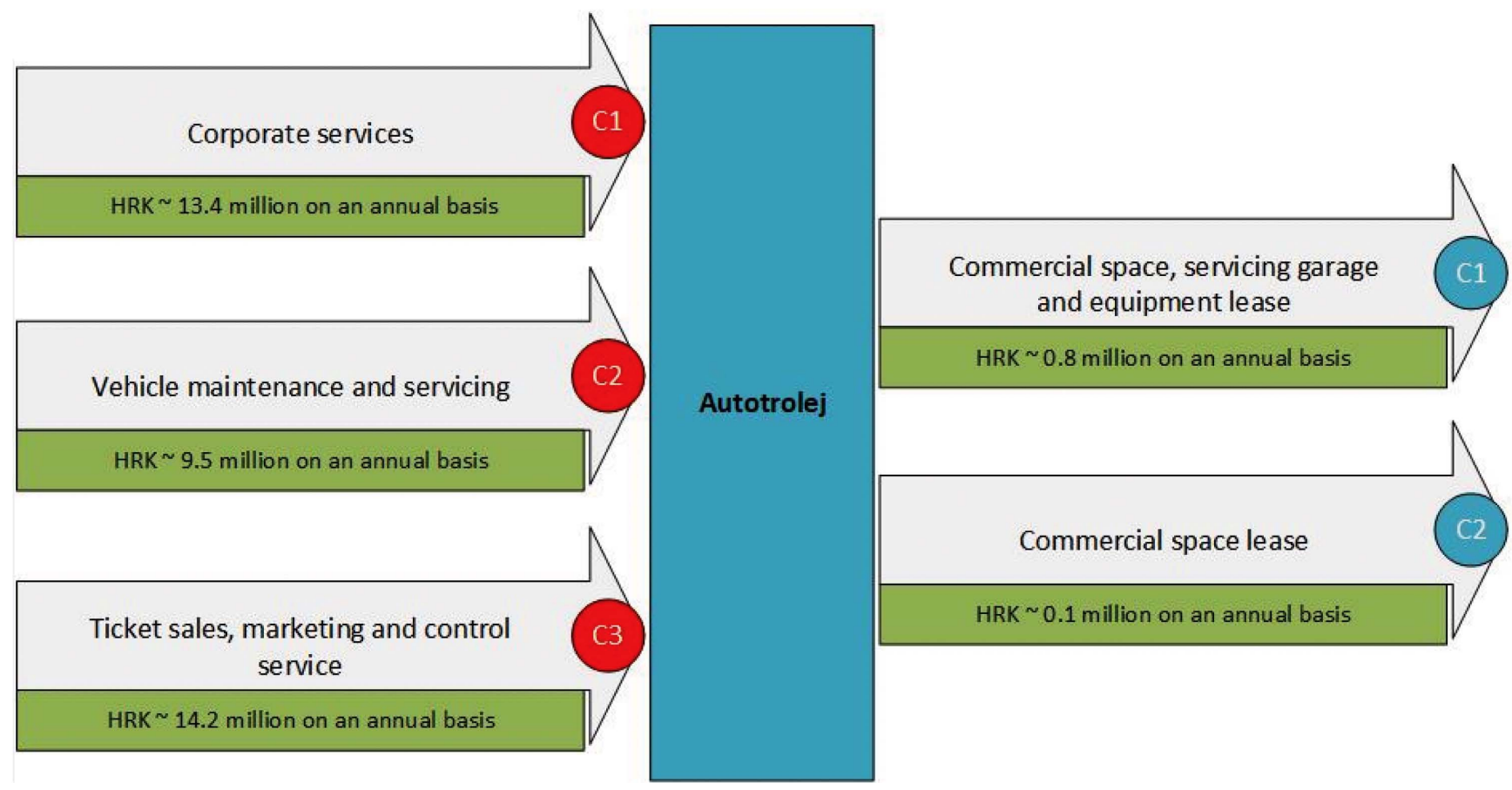

Figure 4 Purchase and sales invoices of the public utility for public passenger transport

Source: $[4]$

- Invoice C2: Vehicle maintenance and servicing which includes: preventive and corrective vehicle maintenance services, vehicle servicing services.

- Invoice C3: The ticket sales, marketing and control services which include: ticket sales, ticket control, sales of free bus capacities, sales of advertising spaces on and in buses.

The sales invoices refer to:

- Invoice c1: Commercial space, service garage and equipment lease by the company for commercial activity to which the public utility for public passenger transport will give the said asset for lease.

- Invoice c2: Lease of the commercial spaces of the companies for the performance of joint activities to which the public utility for public passenger transport will give its spaces for lease.

The company for joint activities in the new organization accepts one type of purchase invoice from, for example, the public utility for public passenger transport and it issues a higher number of sales invoice, for example, three invoices to each of the remaining companies if it will be providing them with corporate services.

The company for commercial activity in the new organization accepts three types of purchase invoices from all companies and issues two types of sales invoices to the public utility for public passenger transport (services regarding the servicing and maintenance of the vehicles of the public utility for public passenger transport and services regarding the ticket sales, marketing and control).

The conclusion of the mutual cooperation agreement is based on a Service Level Agreement (SLA), i.e. an agreement on the level of service which is used for mutual contracting and delivery of services between the service providers and their users. The purpose of the SLA agreement is for both the service provider and the user to additionally arrange their relationship, in mutual interest. The Service Level Agreement is an excellent tool creating mutual understanding regarding the services and delivery of services between the service providers and their users. Furthermore, it helps the service provider explain to the user what it is delivering and how and it guarantees the user that he will be provided with the promised and expected level of service. SLA is both a process and a product (agreement), i.e. a communication channel used to define expectations, clarify the responsibilities and create an objective basis for the assessment of the service effect. The contractual services are mainly a compromise (balance) between quality and quantity of the service delivered and its price [4]. 
In terms of the process, the Service Level Agreement is a formal means of coming to an agreement which is used by two or more parties to improve their communication, build long-term relationships and define expectations regarding the following:

- services, levels and quality of services

- responsibilities of each party

- steps to be taken by all parties to ensure successful relationships.

In terms of the product, it is a document including all the above stated information:

- between the service provider and his internal or external users or

- between any two or more parties which must act jointly to complete a task and achieve a joint objective.

The introduction of the Service Level Agreement ensures a standardised level of services, the level of services is being recorded and documented, the mechanisms for measuring the level of services are being defined for both parties, grounds for the service level improvements are being created, responsibility in the business process is being defined, easier planning and provision of means for the resources in enabled, a higher mobility of all business process participants is also ensured, the functioning of the business process is optimized, the capital resources are better managed and used, a balance is being achieved between the prices and benefits, experience and knowledge in outsourcing negotiations is gained, a culture of giving and receiving (using) the services is created etc. In the new organization the SLA agreements are of key importance for clear defining of the expectations, division of responsibilities and creation of an objective basis for the estimation of the services effect among certain companies [4].

\section{Conclusion}

The organization of the public utility system is of extreme importance once the possibilities of joint actions are taken into consideration, i.e. once the compatibility of their services is determined. The City Companies Association was designed for the purpose of grouping commercial and supporting activities, i.e. their complete extraction into separate companies. The analysis of the public utility system resulted in the establishment of a connection between the services of the public utility company for public passenger transport and the company for road and public traffic area maintenance and vehicle parking and transfer organization. The above mentioned led to a fact that it is a good business decision to separate the commercial services into a separate company and the supporting functions into another separate company. The entire reconstruction enables an increase of the business transparency, the increase of revenue and the quality of service, meanwhile reducing the costs. Separating the utility services and commercial activity was harmonized with the European Union legislation, while the commercial activity was certainly given the possibility to develop services and focus on the generation of revenue. Grouping the supporting functions into a single company for joint activities denotes a uniform quality for all city companies and enables the avoidance of double data, i.e. better workload organization and more precise planning which contributes to an increased productivity. Separating the said work into separate companies enables better utilisation of human resources and a better development of joint processes and services.

\section{References}

[1] AT Kearney: Analiza poslovanja i podizanje razine usluge gradskog prijevoza i prometa, Rijeka, 27.06.2014.

[2] Baričevič, H.: Tehnologija kopnenog prometa, p. 24, Pomorski fakultet u Rijeci, Rijeka, 2001.

[3] Miloš, I.: Tehnologija i organizacija intermodalnog prometa, p. 266, Polytechnic of Rijeka, Rijeka, 2011.

[4] The Boston Consulting Group Servicing LLC: Završni elaborat projekta: "Izdvajanje komercijalne djelatnosti i potpornih funkcija iz KD Autotrolej”, Rijeka, 5.12.2014.

[5] Županović, I.: Tehnologija cestovnog prijevoza, p. 7, Fakultet prometnih znanosti, Zagreb, 2002. 